\title{
Acute Renal Failure due to Leptospirosis grippotyphosa
}

\section{Introduction}

In a minority of previously healthy patients presenting with acute renal failure, infectious agents are responsible for renal deterioration. Isolation of microorganisms is often unsuccessful and therefore a nosological diagnosis difficult. We describe two patients with reversible acute renal failure, which by serological methods proved to be due to infection with Leptospira grippotyphosa. It is considered unusual for this microorganism to raise severe symptoms in humans.

Case 1: A 71-year-old farmer was admitted to our hospital because of a high fever $\left(39.5^{\circ} \mathrm{C}\right)$ for 3 days. The patient was in stable health until 5 days before admission, when fever developed. Two weeks before he had supervised the cleaning of ditches on his farmland. On examination he appeared moderately ill. Body temperature was $39.4^{-} \mathrm{C}$, pulse $78 \mathrm{bpm}$ and blood pressure $110 / 70$ $\mathrm{mmHg}$. No rash or lymphadenopathy was noted. He had a mild conjunctivitis and was not icteric. Examination of lungs, heart, abdomen and neurological examination was normal.

Laboratory data showed renal failure (blood urea $41 \mathrm{mmol} / \mathrm{l}$, creatinine $787 \mu \mathrm{mol} / \mathrm{l}$ ). Bilirubin was normal and liver enzymes were only marginally elevated (ASAT 31 U/L, ALAT 38 U/, normal both $<30 \mathrm{U} / \mathrm{l}$ ). Proteinuria of $5.6 \mathrm{~g} / \mathrm{l}$ was found. The sediment contained no cylinders or leucocytes and only a few red cells were seen. An ultrasound examination of the abdomen was normal. X-ray films of the chest were also normal. Blood and urine cultures were negative. On the first hospital day the patient became anuric. The anuria did not respond to intravenous infusion of 3 litres of saline $0.9 \%$. A Swan-Ganz pulmonary artery catheter was inserted and adequate left ventricular filling pressures were found. On the second hospital day haemodialysis was started. At the fourth hospital day he became polyuric ( $>61 / 24 \mathrm{~h})$ and dialysis was discontinued. During the following days renal function improved. After 12 days he was discharged from the hospital with serum creatinine of $159 \mu \mathrm{mol} / \mathrm{l}$. Renal function gradually reverted to normal in the following weeks. Serum antibodies against $L$. grippotyphosa were demonstrated on the 15 th day after hospitalisation $(\operatorname{IgM} 1: 320, \operatorname{IgG} 1: 1,280)$, and on day 21 after hospitalisation IgM antibodies were negative, while IgG titre amounted to 1:5,120. Leptospira antibodies were detected at the K.I.T. Reference Laboratory for Leptospirosis, Amsterdam, The Netherlands (using ELISA for IgM antibodies, combined with a micro-agglutination test for specific IgG antibodies). Serum antibodies against hantaviruses remained negative.

Case 2: A 47-year-old gardener was admitted to our hospital because of suspected pyelonephritis. He was previously in good health until 4 days before admission when abrupt high fever of $40.5^{\circ} \mathrm{C}$ developed. Cold chills and bilateral flank pain occurred. On examination he was ill, blood pressure $140 / 80 \mathrm{mmHg}$, pulse $100 \mathrm{bpm}$, temperature $39.6^{\circ} \mathrm{C}$. Examination of the chest and abdomen were normal except for renal lodge pain bilateral on palpation. There was no edema. Laboratory data: urea $18.5 \mathrm{mmol} / \mathrm{l}$, creatinine $418 \mu \mathrm{mol} / 1, \mathrm{~K} 4.7 \mathrm{mmol} / 1$, Na $135 \mathrm{mmol} / 1$, Ca 2.13 $\mathrm{mmol} / \mathrm{l}, \mathrm{P} 1.33 \mathrm{mmol} / \mathrm{l}$, bilirubin $<17 \mathrm{mmol} / \mathrm{l}$, direct $<5 \mathrm{mmol} / \mathrm{l}$, AF 47 U/1, ASAT 14 U/l, ALAT 19 U/1, LDH 303 U/1, gammaGT $30 \mathrm{U} / \mathrm{l}, \mathrm{CK} 140 \mathrm{U} / \mathrm{l}$, albumin $40 \mathrm{~g} / \mathrm{l}$. Urinalysis: 0-10 erythrocytes/ $\mu \mathrm{l}$, no leucocytes, no cell cylinders. Proteinuria: $6.9 \mathrm{~g} / 24 \mathrm{~h}$. $\mathrm{X}$-ray of thorax and ECG and ultrasonography showed no abnormalities. The patient recovered completely and renal func- tion was restored, while proteinuria disappeared after 3 days. Serologic data for L. grippotyphosa antibodies: 8 days after hospitalization, no antibodies could be detected, after 18 days IgM titre was 1:320 and IgG titre 1:1,280. Fifty days after hospitalization IgM titre amounted to $1: 80$, while IgG titre rose to $1: 5,120$. Serum antibodies against hantaviruses remained negative.

\section{Discussion}

Both patients presented with acute renal failure due to $L$. grippotyphosa. No signs of Weil's syndrome were present in our patients (clinical syndrome of jaundice, thrombopenia and acute renal failure after infection with leptospirae). Anicteric leptospirosis is considered to be mild and without concurrent mortality [1], however, our two patients presented with severe acute renal failure. Both patients presented with symptoms and signs of acute renal failure suggestive for hantavirus infection (serotype Puumala). It has been encountered several times in our region of the country and also in Germany, in Northrhine-Westphalia, which apparently forms a continuum with the Twente area [2]. In fact, our first impression of the clinical picture was hantavirus nephropathy and therefore we did not perform renal biopsy. In $L$. grippotyphosa field-mice are the main reservoir and inhalation of aerosols, or direct contact with urine, probably causes infection. Diagnosis is primarily serologic; however, diagnosis can also be made by recently developed PCR assays in body secretions [3,4]. Acute renal failure in leptospirosis may be oliguric or non-oliguric [5]. Acute tubular necrosis is also described, either caused by hypoxemia or as a direct toxic effect of leptospirae. Inflammatory changes in the kidney may be seen in the later stages, and in one patient deposition of complement components and electron dense bodies in glomeruli, suggesting immune complex glomerulonephritis, are described [6]. The mechanisms of deterioration of renal function and transient proteinuria have not been elucidated [7]. In this report we present two patients with symptoms and clinical course compatible with hantavirus infection, who were found to be infected by L. grippotyphosa. Zoologic field studies may be needed in the future to investigate rodent reservoirs of leptospirae and hantaviruses, as severe renal failure can occur in humans.

M. N. Gerding, J. Groen, R. L. M. Brouwer, J. G. M. Jordans, A. D. M. E. Osterhaus

\section{References}

1. Kennedy, N. D., Rainford, D. J., Pusey, C. D., Higginson, A.: Leptospirosis and acute renal failure - clinical experiences and a review of the literature. Postgrad. Med. J. 55 (1979) 176-179.

\section{Received: 24 June 1997/Revision accepted: 15 September 1997}

M. N. Gerding, M. D., R. L. M. Brouwer, M. D., J. G. M. Jordans, M. D., Medical Spectrum Twente, Dept. of Internal Medicine, P. O. Box 50000. NL-7500 KA Enschede; J. Groen, Ph. D., Center for Exotic Virus Infections, Dept. of Clinical Virology, University Hospital Rotterdam: $A$. $D$. M. E. Osterhaus, Ph. D., Center for Exotic Virus Infections, Dept. of Clinical Virology, University Hospital Rotterdam and Institute of Virology, Erasmus University Rotterdam, The Netherlands.

Correspondence to: $M . N$. Gerding, M. D., Academic Medical Center, FS-171, Meibergdreef 9, NL-1105 AZ Amsterdam, The Netherlands. 
2. Gerding, M. N., Groen, J., Jordans, J. G. M., Osterhans, A. D. M. E.: Hantavirus nephropathy in the Netherlands: clinical, histopathological and epidemiological findings. Neth. J. Med. 47 (1995) 106-112.

3. Terpstra, W. J.: Serodiagnosis of bacterial diseases: problems and developments. Scand. J. Immunol. 36 (1992) (Suppl. 11) 91-95.

4. Mérien, F., Amouriaux, P., Perolat, P., Baranton, G., Saint-Girons, I.: Polymerase chain reaction for detection of Leptospira spp. in clinical samples. J. Clin. Microbiol. 30 (1992) 2219-2224.

\section{T. Bergan (ed.)}

Infectiology, Vol. 1

Urinary Tract Infections

142 pages, 23 figures, 34 tables

Karger, Basel 1997

Price: DM 134,-

Urinary tract infection is one of the most frequent bacterial infections in humans. Knowledge of its pathogenesis and optimal modes of treatment have advanced rapidly within the recent decade. Books describing the latest developments in research in this field are of particular interest for physicians dealing with urinary tract infections.

This well-structured book comprises contributions to a session held by the International Society of Chemotherapy Commission of Urinary Tract Infections presented at their 19th International Congress in Montreal. In 22 articles (an average of 6 pages each) authors from research groups from Canada, Germany, Hungary, Japan, New Zealand, the Slovak Republic, Sweden, Netherlands and the USA present short reviews or results in selected research fields.

The topics are the treatment of uncomplicated and complicated urinary tract infections (i.e. renal transplant recipients, patients
5. Segure, A. C., Lomar, A. V., Rocha, A. S.: Acute renal failure of leptospirosis: nonoliguric and hypokalemic forms. Nephron 55 (1990) 146-151.

6. Lai, K. N., Aarons, I., Woodroffe, A. J., Clarkson, A. R.: Renal lesions in leptospirosis. Aust. NZ J. Med. 12 (1982) 276-279.

7. Sitprija, V., Pipatanagul, V., Mertowidjojo, K., Boonpucknavig, V., Boonpucknavig, S.: Pathogenesis of renal disease in leptospirosis: clinical and experimental studies. Kidney Int. 17 (1980) 827-836.

with HIV or on anticancer drugs and on glucocorticosteroid therapy), acute and chronic prostatitis (clinical studies, experimental work, animal models), pathogenesis of UTI (adherence, tropism, antibacterial factors, virulence profiles of Escherichia coli). The series of articles concludes with future considerations on research priorities. Each section is followed by $4-48$ references with the most recent dating back to 1996.

The strength of the book is the large number of highly qualified articles in a very confined space, but this is its weakness as well: the authors could not go into detail. Although the title implies comprehensive information concerning urinary tract infection, many of its main clinical aspects (UTI in children and in the elderly, diagnostic evaluation in patients with UTI, congenital anomalies of the urinary tract such as vesicorenal reflux, UTI in voiding disorders, prophylaxis, vaccination, etc.) are not dealt with.

Finally, the book can be recommended for physicians who want a quick overview of some of the modern clinical aspects and research fields in urinary tract infection. It is the encouraging first volume of a series of books named Infectiology focussing on new and improved knowledge in this field of medicine.

R. Beetz

Mainz 